\title{
UNDANG-UNDANG LARANGAN PRAKTIK MONOPOLI DAN PERSAINGAN USAHA TIDAK SEHAT SEBAGAI FAKTOR INTEGRASI DI BIDANG KEGIATAN USAHA
}

\author{
Susi Yanuarsih \\ Fakultas Hukum Universitas Palembang \\ susi.yanuarsi@gmail.com \\ Abstract
}

The law that represents socially agreed upon is to regulate justice in society. As a social institution, the organization that is responsible for the needs of the community must implement it. Therefore a community will hold it in a way that is different from other communities.

Keywords, Political sub-systems; economics; culture and business competition law

\section{Abstrak}

Hukum merupakan institusi sosial yang tujuannya adalah untuk menyelenggarakan keadilan dalam masyarakat. Sebagai suatu institusi sosial, maka penyelenggaraan yang demikian itu berkaitan dengan tingkat kemampuan masyarakat itu sendiri untuk melaksanakannya. Oleh karena itu suatu masyarakat akan menyelenggarakannya dengan cara tertentu yang berbeda dengan pada masyarakat yang lain.

Kata Kunci, sub sistem Politik; ekonomi; budaya dan hukum persaingan bisnis

\section{PENDAHULUAN}

\section{A. Latar Belakang.}

Talcot Parson menempatkan hukum sebagai salah satu sub sistem dalam sistem sosial yang lebih besar. Di samping hukum, terdapat sub-sub sistem lain yang memiliki logika dan fungsi yang berbeda-beda. Sub-sub sistem dimaksud adalah budaya, politik dan ekonomi. (Bernad L Tanya Dkk:2010:152).

Budaya berkaitan dengan nilainilai yang dianggap luhur dan mulia dan oleh karena itu harus dipertahankan. Subsistem ini berfungsi mempertahankan pola-pola ideal dalam masyarakat. Hukum menunjukan pada aturan-aturan sebagai aturan main bersama (rule of the game). Fungsi utama sub sistem ini mengkoordinir dan mengontrol segala penyimpangan agar sesuai dengan aturan main.

Politik bersangkut paut dengan kekuasaan dan kewenangan. Tugasnya adalah pendayagunaan kekuasaan dan kewenangan untuk mencapai tujuan. Setiap masyarakt selalu merupakan suatu kesatuan politik. Artinya masyarakat itu senantiasa berusaha untuk mencapai berbagai tujuan yang dianggapnya baik. Dalam rangka pencapai tujuan ini, suatu masyarakat akan bergerak sebagai suatu kesatuan. Semakin baik sifat kesatuan bergerak mencapai tujuan itu, semakin tinggi jadinya sifat masyarakat itu sebagai suatu kesatuan politik atau masyarakat politik. Oleh karena itu masyarakat itu ternyata juga melakukan tindakantindakan yang dapat digolongkan sebagai tindakan politik. Artinya masyarakat bergerak untuk mencapai tujuan-tujuan tertentu dan dalam rangka itu mengorganisasikan partisipasi masyarakat di dalam usaha tersebut. Dalam kaitannya dengan fungsi politik sebagai alat untuk mencapai kekuasaan dan kewenangan untuk mencapai tujuan perlu adanya aturan main yang diatur oleh hukum sebagai alat kontrol, sehingga penggunaan kekuasaan tersebut tidak absolut.

Sedangkan ekonomi menunjuk pada sumber daya materil yang dibutuhkan menopang kehidupan sistem. Tugas sub sistem ekonomi 
adalah menjalankan fungsi adaptasi berupa kemampuan menguasai saranasarana dan fasilitas untuk kebutuhan sistem. Sub sistem ekonomi yang merupakan penopang dari sub sistem lainnya adalah untuk memenuhi kebutuhan, oleh karena itu dalam pengeloaan sumber daya materil yang ada harus digunakan sebaik-baiknya dengan memperhatikan sistem perekonomian yang dianut oleh sistem ekonomi pancasila sebagaimana termuat didalam konstitusi kita UUD 1945 sebagaimana tercermin di dalam pasal 33.

Sub-sistem budaya, politik dan ekonomi kalau dibiarkan berjalan masing-masing maka akan terjadi berbagai konfliks, karena terjadinya benturan nilai-nilai dari masingmasing sub sistem tersebut. Oleh karena harus ada komponen perekat untuk menyatukan atau mengintegrasikan sub-susb sistem tersebut. Sub sistem itu, selain sebagai realitas yang melekat pada masyarakat, juga serentak merupakan tantangan yang harus dihadapi tiap unit kehidupan sosial. Hidup matinya sebuah masyarakat ditentukan oleh berfungsi tidaknya tiap sub sistem sesuai tugas masing-masing. Untuk menjamin itu, hukumlah yang ditugaskan menata keserasian dan gerak sinergis dari tiga sub sistem yang lain itu.

Posisi hukum begitu sentral di sini. Ia harus mampu menjinakan subsub sistem yang lain agar bisa berjalan sinergis tanpa saling bertabrakan. Sebab, seperti masing-maisng sub sistem tersebut memiliki logika, mekanisme dan tujuan yang berbeda. Di satu sisi, sub sistem budaya cenderung konservatif dan setia mempertahan pola-pola ideal. Pada sisi yang lain, sub sistem ekonomi sangat dinamis dan cenderung melahirkan terobosan-terobosan baru yang bisa saja asing dan liar dari ukuran pola-pola ideal budaya. Sedangkan sub sistem politik senantiasa mencari berbagai cara untuk mencapai tujuan yang boleh jadi cara-cara yang dipakai tidak sesuai dengan polabudaya dan relitas sumberdaya materil itu. Keadaan yang rentang benturan itu. Harus ditangai oleh hukum lewat fungsi pengintegrasiannya agar tiap sub sistem berjalan serasi dan sinergis demi lestarinya sistem.

Pada umunya negara yang sedang berkembang, seperti halnya Indonesia mempunyai keinginan yang kuat untuk melaksanakan pembangunan ekonominya. Dalam upaya membangun perekonomian tersebut, pemerintah menerbitkan kebijaksnaankebijaksanaan deregulasi yang bertujuan untuk membangun perekonomian nasional (Amrizal:1999:35)

Dalam kegiatan usaha tidak terlepas dari pengaruh politik, ekonomi dan budaya. Politik berkaitan dengan kebijakan yang diambil oleh penguasa (pemerintah) dalam mengatur kegiatan usaha dengan mengeluarkan peraturan perundangundangan yang mengatur kegiatan usaha. Ekonomi berkaitan dengan tujuan dari usaha adalah untuk mencari keuntungan (propit), sehingga dalam mencari keuntungan tersebut dilakukan berbagai cara yang bisa saja menimbulkan kerugian terhadap pihak lain. Sedangkan budaya bagaimana mempertahankan pola-pola ideal dalam bertransaksi dalam kegiatan bisnis yang sesuai dengan kebiasaan yang ada dalam masyarakat yang tidak terpangaru oleh faktor lain, sehingga nilai-nilai yang ideal tersebut terkadang diabaikan oleh kemajuan atau pergeseran budaya. Seperti masyarakat lebih senang berbelanja di mall dibandingkan dengan pasar 
tradisional. Untuk mengatasi kesenjangan baik di bidang politik, ekonomi dan budaya tersebut, maka diperlukan hukum sebagai pengintegrasi dari perbedaan tersebut yang tertuang di dalam undangundang. Begitu juga terhadap undangundang tentang larangan praktik monopoli dan persaingan usaha tidak sehat sebagaimana diatur di dalam Undang_undang No. 5 tahun 1999. Yang bertujuan untuk mengatur kegiatan usaha yang fair sehingga tidak menimbulkan kerugian pada masyarakat.

\section{B. Permasalahan}

Bagaimana peran undang-undang larangan praktik monopoli dan persaingan usaha tidak sehat dalam kaitannya dengan teori hukum Parson hukum sebagai faktor integrsi dalam pelaksanaan persaingan usaha?

\section{PEMBAHASAN}

Terlepas dari berbagai kelemahan yang ada, pembangunan ekonomi indonesia selama beberapa dekade belakangan ini telah menghasilkan banyak kemajuan. Kemajuan tersebut didorong oleh kebijakan pembangunan di berbagai bidang, di antaranya kebijakan pembangunan di bedang ekonomi. Namun demikian, meskipun telah banyak kemajuan yang tercapai, anatara lain ditunjukan dengan pertumbuhan ekonomi, masih banyak pula tantangan atau persoalan dalam pembangunan ekonomi yang belum terpecahkan, seiring dengan adanya kecenderungan globalisasi perekonomian serta dinamika dan perkembangan usaha swasta.

Peluang-peluang usaha yang tercipta selama ini kenyataannya belum membuat seluruh masyarakat mampu dan dapat berpartisipasi dalam pembangunan di berbagai sektor ekonomi. Perkembangan usaha swasta selama periode tersebut, di satu sisi di warnai oleh berbagai bentuk kebijakan pemerintah yang kurang tepat sehingga pasar menjadi terdistorsi. Di sisi lain, perkembangan usaha swasta dalam kenyataan sebagian besat merupakan perwujudan dan kondisi persaingan usaha yang tidak sehat.

Fenomena di atas telah berkembang dan didukung oleh adanya hubungan yang terkait antara pengambil keputusan dan para pelaku usaha, baik secara langsung maupun tidak langsung sehingga lebih memperburuk keadaan, penyelenggaraan ekonomi nasional kurang mampu mengacu kepada amanat pasal 33 Undang_undang Dasar 1945, serta cenderung menunjukan corak yang sangat monopolistik.

Para pengusaha yang dekat dengan elite kekuasaan mendapatkan kemudahan-kemudahan yang berlebihan sehingga berdampak kepada kesenjangan sosial, muncul konglomerasi dan sekelompok kecil peengusaha kuat yang tidak didukung oleh semangat kewirausahaan sejati merupakan salah satu faktor yang mengakibatkan ketahanan ekonomi menjadi sangat rapuh dan tidak bersaing.

Memperhatikan situasi dan kondisi tersebut di atas, menuntut kita untuk mencermati dan menata kembali kegiatan usaha di indonesia. Hal ini supaya dunia usaha dapat tumbuh dan berkembang secara benar sehingga tercipta iklim persaingan usaha yang sehat, dan terhindarnya pemusatan ekonomi pada perseorangan atau kelompok tertentu, antara lain dalam bentuk praktik monopoli dan persaingan usaha tidak sehat yang merugikan masyarakat, yang bertentangan dengan cita-cita keadilan sosial.

$\begin{array}{lrr}\text { Dalam aktivitas bisnis dapat } \\ \text { dipastikan terjadi } & \text { persaingan } \\ \text { (competition) di antara pelaku usaha. }\end{array}$


Pelaku usaha akan berusaha menciptakan, mengemas serta memasarkan produk yang dimiliki baik barang/jasa sebaik mungkin agar diminati dan dibeli oleh konseumen, persaingan dalam usaha dapat berimplikasi positif, sebaliknya dapat menjadi negatif jika dijalankan dengan perilaku negatif dan sistem ekonomi yang menyebabkan tidak kompetitif.

Setelah undang-undang persaingan diberlakukan pada tahun 1999 (Undang-Undang No.8 tahun 1999 tentang larangan praktik monopoli dan persaingan usaha tidak sehat), muncul harapan dari masyarakat bahwa undang-undang ini akan memperbaiki apa yang dianggap masyarakat sebagai tindakan anti persaingan oleh berbagai pihak. Misalnya, usaha kecil mengharapkan undang-undang ini akan melindungi mereka dari apa yang mereka lihat sebagai praktik tidak adil dari perusahaan besat. Praktik-pratik ini mungkin sekali tampak tidak adil, tetapi bukan berarti bahwa telah terjadi pelanggaran terhadap undangundang persaingan.

Bagi dunia usaha, persaingan harus dipandang sebagai hal positif. Dalam teori ilmu ekonomi, persaingan yang sempurna (perfect cimpetition) adalah suatu kondisi pasar yang ideal. (Daeng Naja:2009:158). Paling tidak ada empat asumsi yang melandasi agar terjadinya persaingan yang sempurna pada suatu pasar tertentu. Pertama, pelaku usaha tidak dapat menentukan secara sepihak harga atas produk atas jasa. Adapun yang menenukan harga adalah pasar berdasarkan ekuilibrum permintaan dan penawaran (suppaly and demand). Dengan demikian, pelaku usaha dalam persaingan sempurna tidak bertindak sebagai price maker, tetapi hanya bertindak sebagai price taker. Kedua. Barang atau jasa yang dihasilkan oleh pelaku usaha betul-betul sama (product homogenety). Ketiga, pelaku usaha mempunyai kebebsan untuk masuk ataupun keluar dari pasar. Dan keempat, konsuen dan pelaku usaha memiliki informasi yang sempurna (perfect information) tentang berbagai hal, di antaranya kesukaan, tingkat pendapatan, biaya dan teknologi yang digunakan untuk mengasilkan barang atau jasa.

Dalam kegiatan perekonomian, pelaku bisnis merupakan faktor utama yang sangat mempengaruhi kondisi perekonomian, terutama dalam pembuatan kebijakan.pelaku bisnis selaku subyek hukum, kadangkala dapat memaksakan kehendak terhadap regulator atau pembuatan kebijakan, jika pelaku bisnis tersebut telah berhasil menguasai perekonomian nasional suatu negara. Untuk itu, sadar atau tidak sadar kepentingankepentingan pengusaha tersebut akan tercermin atau terakomodasi dalam setiap kebijakan yang dibuat pemerintah. Hal ini perlu dicermati, karena dapat menimbulkan ketidakadilan, sehingga menimbulkan ketimpangan-ketimpangan dalam praktik bisnis. Untuk itu perlu regulasi yang berkeadilan agat tercipta bisnis yang fair.

Memperhatikan kondisis perkembangan perekonomian negara indonesia, maka perlu menata kembali kegiatan usaha di indonesia, agar dunia usaha dapat tumbuh berkembang serta sehat dan benar, sehingga tercipta iklim persaingan usaha sehat, serta terindarnya pemusatan kekuatan ekonomi pada perseorangan atau kelompok tertentu, antara lain dalam bentuk praktik monopoli dan persaingan usaha tidak sehat yang merugikan masyarakat. Untuk mengantisipasi perkembangan tersebut dilahirkan Undang-Undang anti monopoli yaitu undang-undang 
No.5 tahun 1999 tentang larangan praktik monopoli dan persaingan usaha tidak sehat. Undang-undang ini telah diberlakukan sejak awal tahun 2000, dan diprediksikan dalam implementasinya akan mengalami banyak kendala. (M. Diah dan Joni Emirzon: 2003:11).

Di dalam sebuah Undang-undang, termasuk undang-undang tentang anti monopoli dan persaingan usaha tidak sehat ini, tidak terlapas dari pengaruh politik, ekonomi dan budaya. Ketiga sub sistem tersebut satu sama lain akan saling mempengarui dalam pelaksanaan dari undang-undang tersebut. Sub sistem politik bertujuan untuk mencapai tujuan dengan membuat kebijakan-kebijakan atau regulasi yang mementingkan kepentingan politik itu sendiri atau pihak - pihak yang dekat dengan elit kekuasaan, sehingga kebijakan yang diambil oleh penguasa akan menguntungkan pihak-pihak yang dekat dengan kekuasaan tersebut. Di bidang ekonomi persaingan usaha banyak dilakukan dengan cara-cara yang tidak fair, dimana pengusaha besar group atau Holding Company akan melakukan praktik monopoli, ambil saja contoh group salim, yang menguasai pangsa pasar mie instan hampir $90 \%$. Kondisi ini tentunya akan merusak tatanan perekonomian bagi para pengusaha kecil atau pesaingnya dan akan berdampak terhadap masyarakat sebagai konsumen dalam hal pengaturan harga.

Di sisi budaya, tidak terlepas dari cultur dari masyarakat dalam melakukan kegiatan usaha yang lebih cenderung bersifat sosial atau kekeluargaan yang berasal dari nilainilai yang hidup dalam masyarakat yang tidak mengenal adanya praktik monopoli, oligopoli dan sebagainya. Dalam mempertahankan nilai-nilai ideal tersebut sekarang ini tidaklah mudah, karena arus globalisasi dalam bertransaksi begitu cepat masuk dalam budaya masyarakat. Masuk nilai-nilai atau faham individualisme yang merupakan ciri dari ekonomi liberal yang membuat persaingan usaha semakin tajam dan saling menjatuhkan antarpelaku usaha yang satu dengan yang lainnya. Oleh karena itu harus ada undang-undang yang mengatur kepentingan-kepentingan dari sub-sub sistem tersebut.

Politik sebagai salah satu sub sistem dalam kaitannya dengan politik hukum (kekuasaan) yaitu politik perundang-undangan mengenai isi atau objek pembentukan peraturan perundang-undangan. Politik mengenai tata cara pembentukan terkait dengan sisitem hukum dan instrumen hukum yang dipergunakan dalam pembentukan peraturanperundangan.

Hukum merupakan institusi sosial yang tujuannya adalah untuk menyelenggarakan keadilan dalam masyarakat. Sebagai suatu institusi sosial, maka penyelenggaraan yang demikian itu berkaitan dengan tingkat kemampuan masyarakat itu sendiri untuk melaksanakannya. Oleh karena itu suatu masyarakat akan menyelenggarakannya dengan cara tertentu yang berbeda dengan pada masyarakat yang lain.

Di dalam masyarakat dalam konteks masyarakat, maka kita dihadapkan kepada berbagai bidang kehidupan yang juga disebut sebagai sub-sub sistem dari masyarakat sebagai sistem yang lebih besar. Talcott Parson, membuat sub-sub sistem dalam masyarakat. Sub-sub sistem tersebut meliputi budaya, sosial, politik dan ekonomi. Dan fungsi-fungsi primernya budaya mempertahankankan pola, sosial 
integrasi, politik mengejar tujuan dan ekonomi fungsinya adaptasi.

Sebagaimana telah dikemukakan bahwa dalam suatu sistem sosial terdapat suatu interaksi sosial. Hal tersebut didasarkan bahwa pada kenyataannya manusia tidak dapat hidup sendiri, hal ini disebabkan adanya ketergantungan antara seseorang dengan lainnya atau sekelompok orang dengan orang atau sekolompok orang dengan kelompok orang lainnya. Dalam hubungan antara manusia dengan manusia lainnya, yang dianggap paling penting adalah reaksi yang timbul sebagai akibat hubungan-ubungan tersebut. Hubungan-hubungan tersebut merupakan interaksi sosial, yang berarti merupakan hubungan hubungan sosial yang dinamis, yang menyangkut hubungan antar orangorang perorangan, antara manusia dengan kelompok manusia, dan antara suatu kelompok manusia dengan kelompok lainnya.

Adalah suatu kenyataan bahwa suatu masyarakat selama hidupnya akan mengalami perubahan-perubahan dalam berbagai aspek kehidupannya. Perubahan-perubahan tersebut bagi masyarakat yang bersangkutan maupun bagi orang luar yang melihatnya, dapat berupa perubahanperubahan yang tidak menarik dalam arti yang kurang mencolok atau perubahan-perubaan yang terbatas dan yang kecil pengaruhnya.

Dari uraian di atas mengenai interaksi sosial, dapat dikemukanan ciri-cirinya sebagai berikut: interaksi sosial baru dapat berlangsung apabila dilakukan minimal oleh dua orang atau lebih, adanya kontak sosial sebagai tahap awal dari terjadinya interasi, adanya komunikasi sebagai pengatar interaksi, adanya reaksi dari pihak lain atas komunikasi tersebut, adanya hubungan timbal balik yang saling pengarh mempengaruhi antara satu dengan yang lainnya, interaksi berpedoman kepada kaidah-kaidah sebagai acuan dalam interaksi.

Sebagai akibat adanya hubungan tadi, akan terdapat kesadaran dalam diri manusia bahwa kehidupan dan hubungan-hubungan antar manusia di dalam masyarakat sebenarnya berpedoman atau mengacu pada suatu aturan yang oleh sebagian masyarakat seharusnya dipatuhi dan ditaati oleh karena aturan tersebut merupakan patokan atau pedoman baik dalam berperilaku maupun hubungan antar sesamanya. (Otje Salman dan Anthon F Susanto:2012: 9).

Hubungan-hubungan antar manusia serta antara manusia dengan masyarakat atau kelompoknya, diatur oleh serangkaian nilai-nilai dan kaidakaidah dan perikelakuannya lamakelamaan melembaga menjadi polapola.

Masyarakat pada dasarnya terintegrasi atas dasar sepakat para anggota terhadap nilai-nilai kemasyarakat tertentu, yatu suatu kesepakatan bersama (general agreements) yang memiliki daya mengatasi erbedaan-perbedaan pendapat dan kepentingan di antara para anggota masyarakat sebagai suatu sistem fungsional terintegrasi ke dalam suatu bentuk equilibrum.

\begin{tabular}{ccc}
\multicolumn{2}{c}{ Dalam hubungan } & $\begin{array}{c}\text { dengan } \\
\text { proses interaksi }\end{array}$
\end{tabular}
dikemukakan di atas, bahwa adanya fenomena saling merasuki di antara subsistem tersebut antara satu sama lain. Keadaan semacam itu biasanya terjadi saling pertukaran di antara sistem kebudayaan dan sistem sosial, sehingga hal yang semula mask pada sistem kebudayaan kemudian menjadi bagian dari sistem sosial. Fenomena tersebut oleh Parson dinamakan bagian-bagian saling 
perasukan. Melalui bagian-bagian inilah dimungkinkan terjadi saling pertukaran di antara sistem-sistem. Dengan menerima kehadiran fenomena seperti tersebut di atas, Parson melihat sistem sosial sebagai suatu sistem yang terbuka, yaitu yang selalu mengalami proses saling pertukaran dalam bentuk input dan output dalam lingkungannya. (Otje Salman dan Anthon F Sunsanto:2012:16).

$\begin{array}{ccc}\text { Berdasarkan teori } & \begin{array}{c}\text { Parson } \\ \text { desebut }\end{array} \text { serta } & \text { dengan }\end{array}$ mempertahankan penggunaan pendekatan secara sistemik, maka dapat diupayakan untuk melihat bagaimana tempat hukum dalam masyarakat atau dengan kata lain bagaiamana hukum tersebut berkaitan dengan bidang-bidang kehidupan lain dalam masyarakat, untuk memenuhi kebutuhan itu, maka hukum ditempatkan pada kedudukan sentral di tenga-tengah suatu proses hubungan input dan output. Untuk memperjelas hal tersebut, di bawah ini digambarkan suatu ragaan proses-proses fungsional dengan proses-proses kemasyarakat.

Politik sebagai salah satu sub sistem yang orientasinya untuk mencapai tujuan dengan kekuasaan dan kewenangannya, terlihat dari proses politik, proses politik daintaranya adalah dalam hal pembuatan ( undang-undang, peraturan). Di sini pembuatan hukum tidak diliaht sebagai proses hukum teknik, melainkan sebagai manifestasi dari kegiatan politik, yaitu membuat deskripsi mengenai eadaan ideal dan memobilisasi sumber-sumber daya untuk mencapainya melalui penggunaan kekuasaan.

Salah satu aspek dalam kehidupan hukum adalah kepastian, artinya, hukum berkehendak untuk mencitakan kepastian hukum dalam hubungan antar orang dalam masyarakat. Salah satu hal yang berhubungan dengan masalah kepastian hukum adalah masalah dari mana hukum itu berasal, kepastian mengenai asal atau sumber hukum menjadi penting sejak hukum menjadi lembaga yang makin formal.

. Bagi seorong ekonom kebutuhan ekonomi masyarakat itulah yang menyebabkan timbulnya hukum. Bagi sosiolog peristiwa yang terjadi dalam masyarakat itulah yang menjadi sumber hukum. Artinya tergantung dari sudut mana hukum itu ditinjau dan hukum tersebut tidak bisa terlepas dari berbagai aspek lainnya, seperti politik, ekonomi sosial budaya dan sebagainya.

Di samping merupakan tuntutan nasional, undang-undang persaingan usaha (fair competition) juga merupakan tuntutan atau kebutuhan rambu-rambu yuridis dalam hubungan bisnis antarbangsa. Dari sisi kehidupan nasional, jelas bahwa basis kultural (asas kekeluargaa) dan konstirusional (demokrasi ekonomi) kita memang sama sekali menolak praktik-praktik monopolistik dalam kehidupan ekonomi yang merugikan rakyat. Dari sisi hubungan antarbangsa pun apalagi dengan muculnya globalisasi ekonomi yang mengandung makna semakin meningkatnya ketergantungan antarbangsa di berbagai bidang kehidupan (ekonomi), mengharuskan berbagai bangsa menaati rambu-rambu (peraturan) baku dalam bisnis antarbangsa sebagai konsekuensi WTO, APEC, 
AFTA, NAFTA, EC dan sebagainya.

Dalam kaitannya dengan undang-undang anti monopoli dan persaingan usaha tidak sehat dalam implementasinya terkadang tidak efektiv, khususnya terjadinya persaingan tidak sehat antara pedagang kecil dengan supermarket. Hadirnya supermarket seperti Indomaret dan alfamart di tengah-tengah perkampungan masyarakat yang kadangkala antara satu minimarket dengan yang lain jaraknya sangat dekat, kondisi ini tentunya sedikit banyak akan mematikan warungwarung kecil masyarakat. Hadirnya mini market di perkampungan ini tidak terlepas dari kebijakan pemerintah dalam upaya untuk meningkatkan pendapatan asli daerah (PAD) dalam hal pemberian izin mendirikan dan menjalankan usaha mini market di kampungkampung. Pemerintah sebagai pemegang kekuasaan politik dalam upaya meningkatkan pendapatan ekonomi (PAD) perlu memperhatikan pengusaha kecil dalam hal ini warung-warung tradisonial.

Pergeseran budaya masyarakat untuk berbelanja di minimarket tidak bisa dibendung dan dibatasi dan sudah merasuk ke desa-desa, karena masyarakat tentunya akan memilih belanja ditempat yang nyaman, sejuk harga murah dan prestise serta pelayanan yang relatif baik. Sementara warung tradisonal memiliki keterbatasan dan kalah bersaing. Seperti kasus Indomaret. Timbulnya kasus indomaret berawal dari adanya keluhan dari pedagang eceran mengenai praktik monopoli yang dilakukan indomaret. Sebagaimana di diputuskan oleh Majelis KPPU No.
3/KPPU-L-1/2000 bahwa KPPU memerintahkan PT. Indomarco Prismata (IP), selaku pemilik jarangan pasar swalayan Indomaret menghentikan ekspansinya di pasar tradisonal yang berhadapan langsung dengan pengecer kecil.

Meskipun sudah ada putusan KPPU yang melarang indomaret untuk ekspansi di pasar tradisional, kenyataan sekarang untuk di kota palembang khususnya dan sumatera selatan pada umumnya. Gray-gray indomaret hampir di setiap kampung atau sudut jalan ada bahkan sampai di desa- desa, yang tentu saja akan merugikan para pedagang kecil dalam hal ini warung rumahan yang modalnya kecil serta pelayanan tak sebagus dan senayaman pelayanan minimarket. Berdirinya gerai-gerai minimarket baik itu Indomaret dan Alfatmart, tidak terlepas dari peran pemerintah selaku penguasa yang memberikan izin usaha kepada minimarket tersebut.(sub politik)

Pada hal yang menjadi tujuan dari undang-undang larangan praktik monpoli dan persaingan usaha tidak sehat adalah membangun ekonomi untuk mensejahterahkan rakyat indonesia berdasarkan pancasila dan UUD 1945. Di samping itu juga membangun demokrasi di bidang ekonomi mengendaki adanya kesempatan yang sama bagi setiap warga negara untuk berpartisipasi di dalam proses produksi dan pamasaran barang dan jasa, terciptanya iklim usaha yang sehat, efektif dan efisien sehingga dapat mendorong pertumbuhan ekonomi dan bekerjanya ekonomi pasar yang wajar.

Untuk mengatasi pertentangan-pertentangan sub sistem politik, ekonomi dan budaya 
dalam kegatan persaningan usaha tersebut . Maka diperlukan perangkat hukum dalam hal ini adanya peraturan perundanganundangan yang memiliki harmonisasi dan singkronisasi antara peraturan perundanganundangan yang lebih tinggi dengan peraturan pelaksananya. Atau atau harmonisasi antara peraturan perundang undangan yang satu dengan undang-undang yang lain. Sehingga fungsi hukum sebagai faktor integrasi dalam bidang kegiatan persaingan usaha yang sehat dapat terwujud dan yang bermanfaat bagi masyarakat.

\section{PENUTUP}

\section{Kesimpulan}

1. Sebelum lahirnya undangundang tentang anti monopoli dan persaingan usaha tidak sehat, kondisi perekonomian indonesia dalam hal ini kegiatan pelaku usaha banyak sekali melakukan praktik monopoli dengan menggunakan kedekatannya dengan penguasa, sehingga kebijakan yang di ambil oleh penguasa menguntungkan kepentingan usaha mereka, sehingga membuat sistem perekonomian indonesia dikuasai oleh segelintir pengusaha besar yang bernaung dibawah perusahaan group atau Holding company.

2. Persaingan usaha yang tidak sehat itu akan berdampak bagi para pelaku usaha kecil yang secara ekonomi pemodal kecil yang bisa saja mereka ini gulung tikar karena kalah bersaing dan yang paling kena dampaknya secara adalah masyarakat sebagai konsumen.karena dengan praktik monopoli, ologopoli, monopsoni, kartel dan sebagainya ini akan mempengaruhi harga pasar dan pendistribusian barang atau jasa.

3. Untuk menghindari hal itu maka diperlukan undangundang yang mengatur tentang persaingan usaha tidak sehat. Undang-undang No. 5 tahun 1999 tentang larangan Praktik monopoli dan Persaingan usaha tidak sehat. Adalah salah satu sub sistem yaitu sub sistem hukum yang berperan untuk mengintegrasi benturan nilainilai atau kepentingan sub sistem politik, ekonomi dan budaya, dalam bidang kegiatan usaha, sehingga tercipta iklim usaha yang sehat dan kondusif.

\section{Saran}

Untuk mengawasi kegiatan persaingan usaha secara komprehensif, maka perlu dibentuk komisi pengawas persaingan usaha ditingkat daerah, seingga kegiatan usaha yang ada di daerah bisa diawasi, hla ini dikarenakan semakin menjamurnya pengembangan usaha yang bersifat sporadis berdirinya minimarket dan supermarket di desa-desa yang bisa berdampak negatif bagi pengusaha kecil (warung rumahan).

\section{DAFTAR PUSTAKA}

Amrizal, Hukum bisnis risalah Teori dan Praktik, Djambatan, jakarta, 1999

Bernad L Tanya, Yoan Simanjuntak dan Markus Y. Hage, Teori Hukum Strategi Tertib manusia Lintas Ruang dan generasi, Genta Publising, Yogyakarta, 2010

Daeng Naja, Pengantar Hukum bisnis Indonesia, Pustaka Yustisia, Jakarta, 2009 
Susi Yanuarsih, Undang-Undang Larangan Praktik Monopoli Dan Persaingan Usaha Tidak Sehat Sebagai Faktor Integrasi Di Bidang Kegiatan Usaha

Halaman 364-373

Dhaniswara K. Harjono, Pemahaman Hukum Bisnis bagi Pengusaha, PT. RajaGrafindo Persada, Jakarta, 2006.

Dudu Duswara Machmuddin, Pengantar Ilmu Hukum Sebuah Sketsa, Refika Aditama, Bandung, 2003.

Marwah M. Diah dan Joni Emirzon, Aspek-aspek Hukum Persaingan Bisnis Indonesia (perjanjian yang dilarang, perbuatan bisnis yang dilarang dan posisi dominan yang dilarang), Unsri, 2003.

Mustafa kamal, Hukum Persaingan Usaha (teori dan Praktiknya di Indonesia), Rajawali Pers, jakarta, 2010.

Otje Salman dan Anthon F Susanto, beberapa Aspek Sosiologi Hukum, PT. Alumni, Bandung, 2012.

Sulistiowati, Aspek Hukum dan relitas Bisnis Perusahaan Group di Indonesia, Erlangga, jakarta, 2010

Satjipto Rahardjo, Ilmu Hukum, PT. Citra Aditya Bakti, Bandung, 2012,

Soerjono Soekanto, Pokok-Pokok Sosiologi Hukum, Rajawali Pres, jakarta, 1980.

$\begin{array}{llr}\text { pengantar, } & \text { rajawali Presiogi } & \text { suatu } \\ \text { grafindo Persada, Jakarta, } 2012 & \text { Raja }\end{array}$

